\title{
ANALISIS MISKONSEPSI SISWA KELAS XI SMA NEGERI 1 BANAWA TENGAH PADA PEMBELAJARAN LARUTAN PENYANGGA DENGAN CRI (CERTAINTY OF RESPONSE INDEX)
}

\author{
Analysis Misconception of Student in Class XI SMA Negeri 1 Banawa Tengah \\ on Learning of the Buffer Material with CRI (Certainty of Response Index)
}

\author{
* Miftahul Jannah, Purnama Ningsih, dan Ratman \\ Pendidikan Kimia/FKIP - Universitas Tadulako, Palu - Indonesia 94118
}

Received 14 March 2016, Revised 14 April 2016, Accepted 16 May 2016

\begin{abstract}
The aim of this study is to analyze misconception of student in class XI SMA Negeri 1 Banawa Tengah on the buffer material. The type of this research is a description where the subject of research is 41 student. The instrument used is a multiple choice test with reasoned (CRI). It consists of 13 items which is accompanied by questionnaries. The results were obtained information that the students have misconceptions on subconcepts calculate pH buffer and way of working buffer, with amount of 37 students (46\%). students at least experienced a misunderstanding on the component subconcepts buffer and way of working buffer with amount 17 student (21\%). Furthermore, causes of student misconception is due to the lack of interest of student in the buffer solution material (22\%), praconception and less understanding of the concept (80\%), textbook of student (34\%), and model of learning (57\%). The result of this study shows that most of students in class XI SMA Negeri Banawa Tengah have misconception on the buffer material.
\end{abstract}

Keywords: Misconception, CRI (Certainty of Response Index), Buffer

\section{Pendahuluan}

Pendidikan adalah usaha sadar dan bertujuan untuk mengembangkan kualitas manusia. Pada umumnya proses pendidikan dan pembelajaran di sekolah dewasa ini berjalan secara klasikal. Artinya seorang guru didalam satu kelas menghadapi sejumlah besar siswa dalam waktu yang samadengan metode yang sama. Padahal pada dasarnya setiap siswa memiliki sifat yang khas, yaitu terdiri dari keanekaragaman individu yang kemampuannya sangat berbeda, ada siswa yang berkemampuannya tinggi, sedang bahkan dengan kemampuan rendah. Perbedaan individu tersebut tentu akan menimbulkan masalah dalam proses pembelajaran, karena bisa mengalami kesulitan belajar. Mata pelajaran kimia terdiri atas banyak konsep, dari konsep yang sederhana sampai konsep yang lebih kompleks dan abstrak. Setiap konsep memiliki hierarki sesuai dengan sifat, atribut, kedudukan konsep, contoh dan non

\section{*Correspondence:}

Miftahul Jannah

Program Studi Pendidikan Kimia, Fakultas Keguruan dan Ilmu Pendidikan, Universitas Tadulako email: miftahuljannah_sukarman@yahoo.co.id Published by Universitas Tadulako 2016 contoh (Suyanti, 2010). Konsep-konsep dasar kimia mendasari dan membangun konsepkonsep yang lebih kompleks. sehingga dalam mempelajarinya perlu kesinambungan dan pengetahuan hierarkis antar konsep (Winarti, 2001). Pemahaman konsep yang benar merupakan landasan yang memungkinkan terbentuknya pemahaman yang benar terhadap konsep-konsep lain yang berhubungan atau konsep yang lebih kompleks, fakta, hukum, prinsip dan teori-teori dalam sains.

Miskonsepsi merupakan suatu konsepsi seseorang yang tidak sesuai dengan konsepsi ilmiah yang diakui oleh para ahli (Suparno, 2005). Siswa yang mengalami miskonsepsi akan melakukan kesalahan dalam belajar kimia. Kesalahan ini terjadi secara terus menerus serta menunjukkan kesalahan dengan sumbersumber tertentu. Siswa yang mengalami miskonsepsi ini cenderung salah dalam menjawab banyak soal berbeda konteksnya tetapi dasar kontekstualnya sama (Berg, 1991).

Lima hal yang menjadi penyebab miskonsepsi yaitu siswa, guru, buku teks, konteks dan metode mengajar. Penyebab 
miskonsepsi dari siswa terdiri dari berbagai hal, yaitu: prakonsepsi, pemikiran humanistik, pemikiran asosiatif siswa, reasoning yang tidak lengkap, intuisi yang salah, perkembangan kognitif siswa, minat siswa, dan kemampuan siswa (Suparno, 2005).

Siswa yang mengalami kesalahan dalam menjawab soal tidak sepenuhnya mengalami miskonsepsi. Siswa yang keliru dalam menjawab soal bisa saja tidak tahu konsep, salah satu cara untuk mengidentifikasi terjadinya miskonsepsi, sekaligus dapat membedakannya dengan tidak tahu konsep adalah dengan menggunakan identifikasi CRI. CRI merupakan ukuran tingkat keyakinan/kepastian responden dalam menjawab setiap 3 pertanyaan (soal) yang diberikan. CRI biasanya didasarkan pada suatu skala dan diberikan bersamaan dengan setiap jawaban suatu soal. Seorang responden mengalami miskonsepsi atau tidak tahu konsep dapat dibedakan secara sederhana dengan cara membandingkan benar tidaknya jawaban suatu soal dengan tinggi rendahnya indeks kepastian jawaban yang diberikannya untuk soal tersebut (Hasan, dkk., 1999).

Miskonsepsi terlah terjadi pada materi kesetimbangan kimia, terutama ketika pertanyaan menuntut siswa melakukan sintesis dan menerapkan konsep dalam permasalahan kesetimbangan kimia (Bergquist \& Heikkinen, 1990). Miskonsepsi juga terjadi pada hasil uji prestasi kimia dari 1.177 siswa Australia dan 537 siswa Amerika yang tergabung dalam second international science study relatif rendah. Lebih lanjut dikemukakan bahwa rendahnya skor yang diperoleh disebabkan adanya beberapa miskonsepsi, diantaranya siswa kesulitan dengan konsep mol dan menghitung perbandingan stoikiometri (Menis \& Frase, 1992).

Mahasiswa di perguruan tinggi di Afrika Selatan sebagian besar belum memahami secara utuh konsep stoikiometri dan kesetimbangan kimia, yaitu dua konsep yang sangat berkaitan erat. Kesulitan utama dalam memahami kedua konsep ini terletak pada keabstrakannya dan karena diajarkan sebelum siswa mencapai tahap berpikir operasi formal (Huddle \& Pillay, 1996).

Banyak faktor yang menyebabkan siswa tidak mencapai ketuntasan minimum yang ditentukan sekolah dalam belajar kimia, diantaranya yaitu kurangnya pemahaman konsep dan juga banyaknya siswa yang mengalami miskonsepsi. Kurangnya pemahaman konsep tersebut terjadi karena sebagian besar konsep kimia bersifat abstrak, seperti konsep tentang atom, molekul, orbital, kesetimbangan kimia, laju reakasi dan kimia larutan. Beberapa pendapat yang mengatakan bahwa (1) sebagian besar konsep kimia bersifat abstrak, (2) konsep-konsep kimia pada umumnya merupakan penyederhanaan dari keadaan sebenarnya (analogi), (3) konsep kimia bersifat berurutan. Sedangkan miskonsepsi dapat terjadi karena prakonsepsi yang salah (pemahaman atau konsep yang dimiliki oleh siswa sebelum masuk kelas) (Kean \& Middlecamp, 1984)

Penelitian tentang miskonsepsi telah banyak dilakukan diantaranya miskonsepsi pada konsep mol (Vaudhi, 2009). Selanjutnya meneliti tentang kesalahan konsep gaya antar molekul (Winarni, 2006). Beberapa peneliti juga telah melakukan penelitian tentang miskonsepsi seperti penelitian yang telah dilakukan pada konsep stoikiometri (Sembiring, 2004). Selanjutnya konsep hukum perbandingan tetap oleh (Nuraini, 2009). Hasil penelitian yang dilakukan di SMA 1 Malang menunjukkan bahwa hampir seluruh siswa mengalami kesalahan konsep pada konsep hukum gas (Robi'ah, 2009).Penelitian lain juga dilakukan pada konsep larutan asam basa (Al-Athiyyah, 2004) .penelitian juga dilakukan pada konsep larutan (Abidin, 2003). Adapun penelitian menggunakan Certainty of Response Index menunjukkan bahwa pemahaman konsepsi guru di SMA terdiri dari 21\% tahu konsep, $57 \%$ miskonsepsi dan 22\% tidak tahu konsep. Bentuk miskonsepsi guru yang ditemukan terdiri dari 36 bentuk pada materi ikatan kimia (Ardiansyah., dkk., 2014). Penelitian juga dilakukan pada materi Kesetimbangan kimia dimana materi ini merupakan salah satu materi kimia yang diajarkan pada siswa SMA. Materi kesetimbangan kimia mengandung banyak konsep yang rumit, sehingga dianggap sulit oleh siswa dan besar kemungkinan menyebabkan terjadinya miskonsepsi (Yumiati, 2015).

Miskonsepsi dalam pelajaran kimia akan sangat fatal dikarenakan konsep-konsep kimia saling terkait antara satu dengan yang lainnya, sehingga kesalahan konsep di awal pembelajaran akan berpengaruh kepada pelajaran lanjutan, hal ini akan bermuara pada rendahnya kemampuan siswa dan tidak tercapainya ketuntasan belajar. Konsep larutan merupakan bagian dari konsep kimia yang bersifat abstrak, sehingga sering membuat siswa kesulitan dalam memahami konsep ini.

Berdasarka hasil wawancara peneliti dengan salah satu guru mata pelajaran kimia kelas XI SMA Negeri 1 Banawa Tengah, diperoleh 
informasi bahwa siswa mempunyai prakonsepsi yang telah diperoleh dari hasil pembelajaran konsep-konsep sebelumnya (Nikmawati, 2015). Konsep tersebut terus berkembang dari pengalaman belajar siswa sehari-hari, dalam mengalami gejala atau fenomena alam maupun pengalaman belajar pada jenjang pendedikan sebelumnya, baik pada saat siswa berada di kelas X dan bahkan pada saat siswa di SLTP. Berdasarkan hal tersebut peneliti bermaksud untuk melakukan penelitian tentang menganalisis miskonsepsi siswa Kelas XI SMA Negeri I Banawa Tengah pada pembelajaran Larutan Penyangga dengan teknik pengukuran berupa tes yang disertai dengan CRI.

\section{Metode}

Penelitian yang dilakukan merupakan jenis penelitian deskriptif yang menggunakan teknik pengukuran berupa tes yang disertai dengan CRI. Metode CRI dilakukan untuk menekankan pada bentuk miskonsepsi yang lebih spesifik terhadap konsep tertentu.

Secara garis besar penelitian ini dilaksanakan dalam tiga tahap yaitu tahap persiapan, tahap pelaksanaan, dan tahap akhir. Adapun tahaptahap tersebut adalah sebagai berikut:

1.Tahap Persiapan: mencari literatur yang berkaitan dengan judul penelitian, menentukan lokasi penelitian, menentukan populasi dan sampel penelitian, menyusun instrumen yang akan digunakan dalam penelitian dan melakukan validitas tes

2.Tahap pelaksanaan: Observasi, menentukan kelas yang dijadikan sampel dan pemberian tes 3.Tahap Akhir

Kegiatan yang akan dilakukan pada tahap ini adalah tabulasi data, pengolahan data, menganalisis data sampel dan menarik kesimpulan pada laporan hasil penelitian. Teknik pengumpulan data dalam penelitian ini diperoleh melalui tes yang disertai dengan CRI yang diberikan kepada siswa.

Penelitian ini dilaksanakan di SMA Negeri 1 Banawa Tengah. Pelaksanaan penelitian pada semester genap tahun pelajaran 2014/2015. Waktu pelaksanaan penelitian yaitu bulan Februari sampai bulan April 2015. Populasi dalam penelitian ini sekaligus jadi sampel penelitian, yaitu semua siswa XI IPA SMA Negeri 1 Banawa Tengah dengan jumlah 41 siswa yang terdaftar pada tahun ajaran 2014/2015. Pengambilan sampel ini dilakukan dengan teknik pengambilan sampel secara menyeluruh.
Instrumen dalam penelitian ini berupa tes hasil belajar siswa dengan tipe soal adalah pilihan ganda yang disertai dengan pemberian alasan dan CRI. Tes ini digunakan sebagai tes untuk mengetahui perbedaan siswa yang tahu konsep, tidak tahu konsep dan miskonsepsi pada hasil tes. Melalui alat ini diharapkan dapat mengungkapkan data penguasaan siswa terhadap konsep-konsep kimia pada materi Larutan Penyangga yaitu: Komponen larutan penyangga dan cara kerja larutan penyangga, menghitung $\mathrm{pH}$ larutan penyangga, pengertian larutan penyangga dan fungsi larutan penyangga.

Penetapan konsep mana yang paling dipahami secara miskonsepsi oleh kelompok responden dapat dilakukan dengan cara identifikasi miskonsepsi secara kelompok. Identifikasi miskonsepsi secara kelompok didasarkan pada rata-rata indeks CRI dari responden yang menjawab benar (CRIB) dan rata-rata indeks CRI dari responden yang menjawab salah (CRIS), dan fraksi responden yang menjawab benar $(\mathrm{Fb})$. Perhituangan nilai CRIB, CRIS dan $\mathrm{Fb}$ menggunakan rumus: (Ulin \& Sukarmin, 2013)

$$
\begin{array}{ll}
\text { CRIB } & =\frac{\text { total jumlah CRI dari jawaban benar }}{\text { jumlah siswa yang menjawab benar }} \\
\text { CRIS } & =\frac{\text { total jumlah CRI dari jawaban salah }}{\text { jumlah siswa yang menjawab salah }} \\
\text { Fraksibenar } & =\frac{\text { junlah siswa yang menjawab benar }}{\text { total jumlah siswa }}
\end{array}
$$

Berdasarkan nilai CRIS dinyatakan terjadi miskonsepsi jika $2,5<$ CRIS $\leq 5$ dan derajat atau dampak miskonsepsi dinyatakan kuat jika nilai CRIS besar dan nilai Fb kecil (Hasan, dkk., 1999).

Angket adalah alat pengumpul data untuk kepentingan penelitian. Angket digunakan dengan mengedarkan forrnulir yang berisi beberapa pertanyaan kepada beberapa subjek penelitian (responden) untuk mendapat tanggapan secara tertulis (Rahayu, 2007). Melalui angket ini dapat mengungkapkan penyebab miskonsepsi dari siswa pada materi larutan penyangga.

\section{Hasil dan Pembahasan}

Tingkat pemahaman siswa pada setiap konsep dapat dibedakan dengan cara membandingkan benar tidaknya jawaban suatu soal dengan tinggi rendahnya skor CRI yang diberikannya untuk soal tersebut. Berdasarkan skor CRI dapat diketahui siswa yang paham konsep, mengerjakan dengan menebak (lucky 
guess), miskonsepsi, dan tidak tahu konsep. Siswa telah paham konsep apabila jawaban siswa benar dan memberikan CRI tinggi (3, 4 atau 5). Siswa mengalami miskonsepsi apabila jawaban siswa salah dan memberikan CRI tinggi (3,4 atau 5) (Hasan, dkk., 1999).

Berdasarkan hasil tes, siswa mengalami miskonsepsi pada setiap konsep/subkonsep perhitungan kimia. Setiap siswa memiliki bentuk miskonsepsi yang berbeda pada setiap subkonsep. Sebagian siswa memiliki dua bentuk miskonsepsi pada satu sub konsep yang ada, sebagai contoh pada subkonsep menghitung $\mathrm{pH}$ larutan penyangga asam dan larutan penyangga basa. 7 dari 19 siswa yang memiliki miskonsepsi dengan menjawab soal dengan menggunakan rumus yang salah dengan menyatakan rumus untuk larutan penyangga asam adalah rumus larutan penyangga basa. Ini menunjukkan pemahaman awal siswa mengenai rumus menghitung $\mathrm{pH}$ larutan penyangga masih belum tepat.

Setiap subkonsep siswa memiliki bentuk miskonsepsi yang berbeda. Miskonsepsimiskonsepsi ini menyebabkan siswa salah dalam menjawab soal yang diberikan. Siswa menjawab soal berdasarkan penguasaan konsepnya yang keliru. Penguasaan konsep yang keliru akan menyebabkan konsep selanjutnya yang saling berkaitan juga menjadi keliru. Ini ditunjukkan pada fungsi larutan penyangga, dimana siswa beranggapan bahwa $\mathrm{HCO}_{3}-\mathrm{CO}_{3}{ }^{2-}$ merupakan sistem penahan utama dalam darah, hal ini menandakan siswa mengalami miskonsepsi.

Berdasarkan hasil yang telah diperoleh kita dapat memperhatikan histogram dalam Gambar 1.

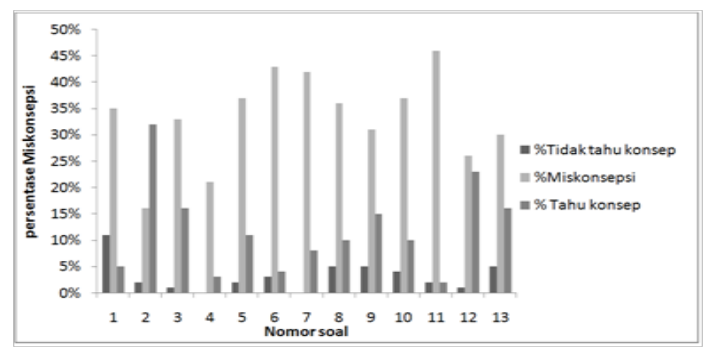

Gambar 1. Histogram Persentase Responden Siswa Kelas IX IPA yang Tahu Konsep, Tidak Tahu Konsep dan Miskonsepsi pada Larutan Penyangga

Berdasarkan Gambar 1 dapat diberikan analisis sebagai berikut: (1) masih ditemukan sejumlah siswa yang mengalami miskonsepsi pada seluruh konsep larutan penyangga dalam jumlah yang sangat bervariasi. Rata-rata siswa yang mengalami miskonsepsi adalah 35\%. (2) pada konsep nomor 1 (komponen larutan penyangga dan cara kerja larutan penyangga) masih ditemukan siswa yang tidak tahu konsep dengan persentase 11\%. Histogram Gambar 1 di atas menunjukkan bahwa besarnya miskonsepsi pada konsep nomor 11 yaitu menghitung $\mathrm{pH}$ larutan penyangga sebesar $46 \%$, untuk memverifikasi hasil penetapan ini dilakukan dengan cara identifikasi miskonsepsi secara kelompok. Identifikasi miskonsepsi responden siswa kelas XI IPA secara kelompok didasarkan pada rata-rata nilai CRI dari responden yang menjawab benar (CRIB) dan responden yang menjawab salah (CRIS) dan fraksi responden yang menjawab benar (Fb). Nilai CRIB, CRIS, dan $\mathrm{Fb}$ dapat dilihat pada Gambar 2.

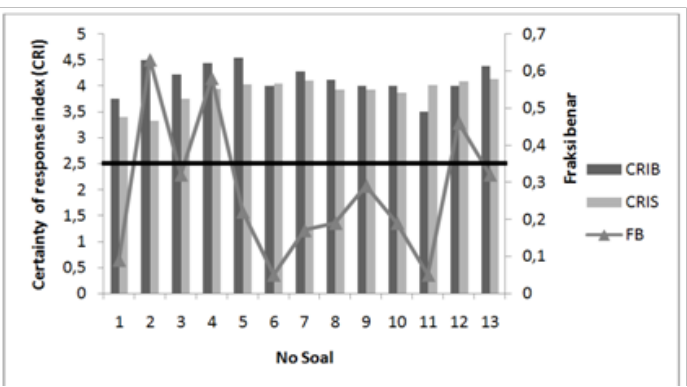

Gambar 2. Grafik perbandingan rata-rata CRI jawaban benar dan salah, dan fraksi benar yang menjawab benar $(\mathrm{Fb})$

Berdasarkan data pada Gambar 2 dapat diberikan hasil analisis sebagai berikut: (1) dengan berdasarkan nilai CRIS maka ada 2 konsep dari 13 konsep yang diujikan masih menyisakan sejumlah siswa yang mengalami miskonsepsi. (2) nilai CRIS terbesar terjadi pada konsep nomor 6 yaitu menghitung $\mathrm{pH}$ larutan penyangga dan konsep nomor 13 yaitu fungsi larutan penyangg. (3) pada konsep nomor 6 (menghitung $\mathrm{pH}$ larutan penyangga) memiliki nilai CRIS besar 4,05 (hampir maksimum 5) dan nilai $\mathrm{Fb}$ sangat kecil $(0,05)$ dinyatakan sebagai konsep yang dampak miskonsepsinya sangat kuat. Untuk melihat penyebab miskonsepsi pada siswa dilakukan pembagian angket kepada siswa yang mengalami miskonsepsi. Dari jawaban angket siswa yang mengalami miskonsepsi diperoleh hasil sebgai berikut:

1)Siswa kurang berminat dan senang dalam mengikuti pembelajaran kimia materi pokok larutan penyangga.

2)Waktu yang disediakan untuk proses pembelajaran subpokok bahasan larutan 
penyangga masih kurang untuk konsep larutan penyangga.

3)Model pembelajaran yang dipilih untuk mengajarkan materi larutan penyangga masih kurang sesuai dengan karakter materi yang diajarkan.

4)Siswa kurang memahami buku bahan ajar sehingga siswa perlu penjelasan tetntang konsep larutan penyangga.

Berdasarkan hasil analisis tersebut, miskonsepsi siswa disebabkan oleh 4 hal, yaitu sebagian siswa kurang berminat dalam materi larutan penyangga (22\%), prakonsepsi atau kurang memahami konsep karena kurangnya penjelasan tetntang konsep larutan penyangga pada proses pembelajaran $(80 \%)$, buku paket siswa (34\%). Dan model pembelajaran (57\%).

Setiap miskonsepsi siswa yang sama belum tentu disebabkan hal yang sama. Siswa paling banyak mengalami miskonsepsi yang disebabkan oleh prakonsepsi yang salah atau kurangnya pemahaman konsep (80\%). Prakonsepsi yang salah akan mempengaruhi pembentukan konsep yang selanjutnya (Suparno, 2005). Sehingga pada konsep yang dipelajari selanjutnya siswa mengalami miskonsepsi.

\section{Kesimpulan}

Berdasarkan hasil penelitian, analisis hasil penelitian dan pembahasan, disimpulkan bahwa hampir seluruh siswa kelas XI IPA SMA Negeri 1 Banawa Tengah masih mengalami miskonsepsi pada subpokok larutan penyangga.Siswa paling banyak mengalami miskonsepsi pada subkonsep menghitung $\mathrm{pH}$ larutan penyangga pada soal 11 sebanyak 37 siswa (46\%) dan pada soal no 6 sebanyak 35 siswa (43\%). siswa paling sedikit mengalami miskonsepsi pada subkonsep komponen larutan penyangga dan cara kerja larutan penyangga pada soal 2 sebanyak 13 siswa $(16 \%)$ dan pada soal nomor 4 sebanyak 17 siswa (21\%). Penyebab miskonsepsi siswa yaitu kurangnya minat siswa dalam materi larutan penyangga (22\%), prakonsepsi atau kurang memahami konsep karena kurangnya penjelasan tentang konsep larutan penyangga pada proses pembelajaran $(80 \%)$, buku paket siswa (34\%) dan model pembelajaran (57\%).

\section{Ucapan Terima Kasih}

Penulis mengucapkan terima kasih kepada kepala sekolah SMA Negeri 1 Banawa Tengah dan semua pihak yang telah membantu dalam pelaksanaan penelitian ini.

\section{Referensi}

Abidin, A. (2003). Analisis miskonsepsi siswa kelas II SMU Negri I Tanjung Pura pada konsep larutan tahun ajaran 2002/2003. Universitas Negeri Medan, Medan.

Al-Athiyyah, Z. (2004). Efektifitas penggunaan model konstruktivisme untuk mencegah miskonsepsi kimia siswa smu pada knsep larutan asam-basa. Universitas Negeri Medan, Medan.

Ardiansyah., Eny. E., \& Ira, L. (2014). Miskonsepsi guru SMA Negeri pada materi ikatan kimia menggunakan certainty of response index (CRI). Universitas Tanjungpura, Jurusan kimia.

Berg, E. (1991). Miskonsepsi fisika dan remediasi. Salatiga: Universitas Kristen Satya Wacana.

Bergquist, W., \& Heikkinen, H. (1990). Student ideas regarding chemical equilibrium, what written test answers do not reveal. Journal of Chemical Education, 67(12), 1000-1003.

Hasan, S., Bagayoko, D., \& Kelley, E. L. (1999). Misconseptions and the certainty of response index (CRI). Jurnal of Physics Education, 34(5), 294-299.

Huddle, P. A., \& Pillay, A. E. (1996). An in-depth study of misconceptions in stoichiometry and chemical equilibrium at a South African university. Journal of Research in Science Education, 33(1), 65-67.

Kean, E., \& Middlecamp, C. (1984). Panduan belajar kimia dasar. Jakarta: Gramedia.

Menis, J., \& Frase, B. J. (1992). Chemistry achievement among grade 12 students in Australia and the United States. Research and Science and Technological Educatio, 10(2), 131-170.

Nikmawati. (2015). Personal komunikasi. SMA Negeri 1 Banawa Tengah.

Nuraini. (2009). Identifikasi konsep sukar dan kesalahan konsep bukum perbandingan tetap siswa MAN 3 Malang. Malang, FMIPA Universitas Negeri Malang.

Rahayu, M. (2007). Bahasa Indonesia di perguruan tinggi. Jakarta: Grasindo. 
Robi'ah, A. (2009). Identifikasi konsep sukar dan miskonsepsi hukum gas pada siswa Negeri 1 Malang. FMIPA Universitas Negeri Malang, Malang.

Sembiring, I. (2004). Miskonsepsi siswa tentang stoikiometri pada siswa kelas II SMUN-I Berastagi T.A 2002/2003. Universitas Negeri Median, Medan.

Suparno, P. (2005). Miskonsepsi dan perubahan konsep dalam pendidikan fisika. Jakarta: Grasindo.

Suyanti, D. R. (2010). Strategi pembelajaran kimia. Yogyakarta: Graha.

Ulin, W., \& Sukarmin. (2013). Pengembangan software pendeteksi miskonsepsi kimia software development for detecting chemical misconceptions. Journal of Chemical Education, 2(3), 85-89.
Vaudhi, F. (2009). Identifikasi konsep sukar dan kesalahan konsep mol pada siswa SMA Negeri I Malang. FMIPA Universitas Negeri Malang, Malang.

Winarni, S. (2006). Koreksi kesalahan konsep gaya-gaya antarmolekul (intermolecular forces) dengan menggunakan strategi konflik kognitif pada mahasiswa kimia Universitas Islam Negeri (UIN) Malang. Universitas Negeri Malang, Malang.

Winarti, A. (2001). Pembelajaran ilmu kimia dan kontribusinya terhadap perkembangan intelektual. Jurnal Vidya Karya XIX, 2, 109115.

Yumiati. (2015). Analisis miskonsepsi dengan teknik certainty of response index (CRI) termodifikasi pada materi kesetimbangan kimia siswa sma dan upaya perbaikannya menggunakan strategi konflik kognitif. Program studi pendidikan kimia, Universitas Negeri Malang. 